REVISTA de

PEDAGOGIE

http://revped.ise.ro

Print ISSN 0034-8678; Online ISSN: 2559 - 639X

\title{
HIGHER EDUCATION IN ONLINE ENVIRONMENT - CHALLENGES AND POSSIBLE SOLUTIONS
}

Educaţia universitară în mediul online - provocări şi posibile soluţii

\section{Luminiţa Mihaela DRĂGHICESCU, loana STĂNCESCU}

\author{
Journal of Pedagogy, 2021 (1), 51 - 72 \\ https://doi.org/10.26755/RevPed/2021.1/51
}

The online version of this article can be found at: http://revped.ise.ro/en/2021/



This work is licensed under the Creative Commons Attribution-NonCommercial-ShareAlike 4.0 International License. To view a copy of this license, visit http://creativecommons.org/licenses/by-nc-sa/4.0/ or send a letter to Creative Commons, PO Box 1866, Mountain View, CA 94042, USA.

\author{
Published by: \\ Centrul Național de Politici și Evaluare în Educație \\ UNITATEA DE CERCETARE ÎN EDUCAȚIE \\ http://www.ise.ro/ \\ https://rocnee.eu/
}

Further information about Revista de Pedagogie - Journal of Pedagogy can be found at: Editorial Policy: http://revped.ise.ro/editorial-policy/ Author Guidelines: http://revped.ise.ro/en/author-guidelines/ 


\title{
HIGHER EDUCATION IN ONLINE ENVIRONMENT - CHALLENGES AND POSSIBLE SOLUTIONS
}

\section{Lumini a Mihaela Drăghicescu* Ioana Stăncescu**}

\author{
Valahia University of Târgovişte, \\ Teacher Training Department, \\ Târgovişte, Romania \\ lumidraghicescu@yahoo.com,stancescu_ioana@yahoo.com
}

\begin{abstract}
In the current national and international context, the education "hosted" in the online environment, which was once only a secondary solution, rarely used, has become the main way to ensure the continuity of the learning process.

In this study, we aimed to capture the reactions of those who were the first to experiment an exclusively online, learning process, i.e. the reactions of the students. We used an investigative approach focused on the following objectives: identifying the perception of students/learners regarding the efficiency and quality of the educational process carried out in the online environment and highlighting ways to improve teaching activities conducted online.

The main research method was the questionnaire-based survey. The questionnaire was administered online, integrating a series of items that addressed issues such as: students' participation in educational activities, problems encountered, solutions to optimize the didactic process conducted in the online environment.

Following the investigative approach, the main conclusions are the following: most of the surveyed students consider that the educational activities carried out in the online environment do not have the same efficiency as the direct activities (face to
\end{abstract}

\footnotetext{
* Associate Professor PhD., Teacher Training Department, Valahia University of Târgovişte, Târgovişte, Romania.

** Lecturer PhD., Teacher Training Department, Valahia University of Târgoviş̧e, Târgovişte, Romania.
} 
face); the main problems highlighted by the respondents were: overload, fatigue, demotivation, learning difficulties in understanding and operating with certain content, poor Internet connection, but also the lack of necessary indications to facilitate learning.

We appreciate that the results of our study may be relevant for practitioners in the field of education, especially for those from higher education, but also for all those interested in digital education.

Keywords: digital competences, digital resources, online education, quality of university education, reflective practice.

\section{Rezumat}

In contextul na ional şi interna ional actual, educa ia ,găzduită” în mediul online, cândva doar o solu ie secundară, la care se recurgea rar, a devenit principala modalitate de a asigura continuitatea procesului de învă are.

In studiul de fa ă, ne-am propus să surprindem reac iile celor care au experimentat primii ceea ce înseamnă un proces de învă ământ derulat exclusiv online, respectiv reac iile studen ilor, prin intermediul unui demers investigativ axat pe următoarele obiective: identificarea percep iei acestora cu privire la eficien a şi calitatea procesului educa ional desfăşurat în mediul online şi eviden ierea unor modalită $i$ de îmbunătă ire a activită ilor didactice realizate în sistem online.

Principala metodă de cercetare utilizată a fost ancheta pe bază de chestionar. Acesta a fost administrat online, integrând o serie de itemi care au vizat aspecte precum: participarea studen ilor la activită ile educa ionale, beneficii ale educa iei online, probleme întâmpinate, solu ii pentru optimizarea demersului didactic desfăşurat în mediul online.

In urma demersului investigativ, men ionăm ca principale concluzii următoarele: majoritatea studen ilor chestiona $i$ consideră că activită ile educa ionale desfăşurate în mediul online nu au aceeaşi eficien ă ca şi activită ile directe (de tip fa $\breve{a}$ in fa $\breve{a}$ ); principalele probleme eviden iate de reponden $i$ au fost: supraîncărcarea, oboseala, demotivarea, dificultă i în învă are, în în elegerea şi operarea cu anumite con inuturi, conexiunea slabă la Internet, dar şi absen a indica iilor necesare pentru facilitarea învă ării.

Apreciem că rezultatele studiului nostru pot fi relevante pentru practicienii din domeniul educa ional, în mod special pentru cei din învă ământul universitar, dar şi pentru to i cei interesa i de problematica educa iei digitale.

Cuvinte-cheie: calitatea educa iei universitare, competen e digitale, educa ie online, practică reflectivă, resurse digitale. 


\section{Introduction}

The pandemic generated by the SARS-CoV-2 virus has triggered a fundamental "paradigm" change worldwide: real life has become "the second life", and the life in the online environment has "triumphed", forcing us all to adapt in an emergency regime and to find in us the strength, the necessary resources to "function" optimally, overcoming "barriers", overcoming our fears, prejudices or attitudes of resistance to change.

No one was prepared to react promptly and effectively in such a crisis situation, so neither did the education system. Moreover, the pandemic highlighted the deficiencies of formal education where investments had been scarce and the importance of which had never been valued in accordance with its major importance for both individual and social development. Thus, referring to higher education, even if a digital infrastructure, more or less adequate, existed in each university, conducting the academic activities online has generated a number of difficulties such as: not all professors and all students have had access, from the beginning, to equipment that would allow them a fast transfer in the virtual environment; those who benefited from the necessary devices, often faced the problem of a sluggish Internet connection; in addition, even some of the students belonging to the digital native generation encountered obstacles in using certain devices, and some professors had to accept a change in roles and develop their digital competences guided by their own students.

Besides, as shown in Education and Training Monitor 2020. Teaching and learning in a digital age, contrary to our perception of them, digital natives do not automatically develop digital competences just because they grow up using digital devices (European Commission, 2020, p. 12). Beyond the digital competences and necessary equipment, both professors and students have found, however, quite quickly, that the teaching-learningassessment processes conducted in the online environment cannot be transferred as such from the course/seminar room.

Despite these shortcomings, we cannot ignore the major benefit of this period: the integration, even if forced, of technology in tertiary education, respectively in formal education in Romania, in general. That was the beginning of a process that had been always delayed, albeit so necessary in an era we call digital: the digitalization of education. 
In a digital world, which interferes with the professional and personal life of each of us, education, especially tertiary education, has a crucial role to play, to equip us with sets of competences (among which the digital competence is pivotal), to cultivate our professional and social qualities, to form our capacities, attitudes that allow us to function harmoniously, to be creative, innovative, resilient, flexible, with a disposition for continuous learning, for constant investment in our own becoming.

As highlighted in a report entitled The 2018 International Computer and Information Literacy Study (ICILS). Main findings and implications for education policies in Europe, digitalization is not just about providing ICT equipment to students and professors (European Commission, 2019, p. 20). The deficit in the area of digital competences can be overcome if professors and students are encouraged and supported to integrate digital tools in the teachinglearning-assessment process, which implies, first of all, a confident attitude of professors in the use of ICT, respectively overcoming barriers related to mentality, routine "built" over time, pedagogical conception, etc.

The success of the process of education digitalization is conditioned, first of all, by the investment in the initial and continuous training of the teaching staff, at any level of education, a process that must necessarily integrate a consistent component of their instrumentation with digital competences, but also with an adequate conception of what digital education means.

Digitalization, assumed at the level of tertiary education, can change the perception on universities, often labeled as ivory towers (Chircop et al., 2020), connecting them to social realities and challenging them to update their instructional practices, so as to facilitate the transition from a professor-centered process to an authentic student-centered educational process (OECD, 2020).

\section{Online higher education - between challenges and solutions}

2.1. The migration of university education in the online environment

The COVID-19 pandemic forced the universities, the schools around the 
world to urgently find solutions to ensure the continuity of the educational process. As each university was "equipped" with at least one e-learning platform, the solution was promptly identified: we fully transfer the teachinglearning-assessment approach to the online environment.

The difficulties, the problems, but also their possible solutions followed one another in an accelerated rhythm. We move the education to the online environment, but how do we proceed?

How do we teach, if the platform does not have the possibility to organize lectures/activities in videoconferencing system? How do we mediate students' contact with certain types of content? How do we develop their targeted competences through various disciplines of study, many of them requiring interaction, direct communication or presence in a laboratory equipped with a series of materials and specific tools? Are the learning resources used so far by professors and students enough? Have we created a sufficient number of open educational resources relevant to those learning outcomes we expect? How do we get feedback on the efficiency of teaching and learning? How do we evaluate the learning results correctly, objectively? And, of course, the questions about what the academic activity means, which came down to a form of education "delivered" exclusively online, were much more numerous.

The major gain of this period was, not only in the development of the professors' digital competences, but also in their reflective ones. The reflective practice, perhaps unknown to some until now, has become an organic component of their educational work for the most committed of professors. Reflectivity integrated in the teaching act implies the systematic re-evaluation of teaching experiences in order to improve future teaching practices (Ashwin et al., 2015, as cited in Klemenčič, Pupinis \& Kirdulytë, 2020, p. 115). Thus, in the new context of conducting university education, almost every course and seminar activity became a source of new problems that urged reflection, research, creativity and innovation, steps that forced professors to get out of their comfort zone, i.e., the daily "routine", out of "the bubble" of their own discipline and to look for solutions, together with other colleagues and together with their students.

Since the campuses closed and our students have had to find ways to 
participate in the educational process, we have all found that the inequities continue to strongly impact the access to education. In fact, it was visible everywhere in the world. The European Commission Report - The European Higher Education Area in 2020: Bologna Process Implementation Report, clearly shows that digitalization alone cannot solve the problems caused by inequity, given that for people from different social groups, from disadvantaged communities located either in urban areas, or in remote rural areas, the learning has been affected by limited access to technology (European Commission/EACEA/Eurydice, 2020, p. 160).

There are still no clear statistics to show us how many of the students dropped out of university, failing in their attempt to build a secure, sustainable future. In another situation were the universities in which the didactic approach, in the case of certain disciplines, promotes a mixed learning process, which combines teacher-led learning sequences with the autonomous work of students, performed in the virtual environment. The results of a study targeting students who benefited from such an approach, show that the physical closure of course/seminar rooms did not have a major impact on them. The transfer of academic activities in the online environment generated small adjustments, in the sense that students were provided with video tutorials and e-mail communication was accentuated, without an extra - exaggerated - volume of work for either of the two primary educational actors (Area-Moreira, Bethencourt-Aguilar \& Martín-Gómez, 2020, p. 49). But what will be the impact of a forced "migration" in the online environment on our students, whose academic activity took place, almost exclusively, in the traditional way, taking the form of face-to-face meetings with the professor? This was, in fact, the question that triggered our investigative approach.

What we need to clarify about the change in academic educational practices immediately after the beginning of the COVID-19 pandemic is that they cannot be subsumed to an authentic online education, but they are circumscribed to the concept of emergency remote teaching (ERT). This is a temporary replacement of classical teaching with an alternative mode of teaching, due to a crisis situation. In such contexts, the main goal is not to recreate a robust educational ecosystem, but to provide temporary access to training materials, in a way that is quickly configured and available, reliably (Hodges et al., 2020). 
Emergency remote teaching has the following characteristics: limited time available for course design and development; reduced assistance in designing and facilitating training; limited or unavailable support for faculty/professors and students; an attitude of discomfort associated with the new online format of academic activity; limited time to ensure quality indicators relevant to the educational approach; accomplishing this approach in a unique framework (O’Keefe et al., 2020).

In contrast to this type of teaching, the authentic online education involves a consistent investment of resources to build a solid ecosystem, defined by the following elements: teaching and learning are planned and efficient; the instructional design is more developed and the whole process is planned; community development and involvement are built through learning, "incorporated" into the learning process; in the initial period, there are different support systems for the student; more time is allocated to prepare the faculty for such an approach; ensuring the quality of learning is an objective to be assumed and integrated into the process; equity and personalization are also ensured (O'Keefe et al., 2020).

The crisis we are going through requires the realization of "a concentrated investments in people and technology to renew and revitalize our pedagogical and social values" (Kalantzis \& Cope, 2020). We can start by integrating into the university space, regardless of other variables of the social context, specific aspects of online teaching-learning. Thus, modern innovative teaching strategies, such as flipped classroom, blended learning, mixed, based on autonomous learning competences, on metacognitive competences, etc. of students, becomes a priority "to do" for the academic environment and a guarantee of a university education adapted to the digital society, ensuring the adequate preparation of its beneficiaries for the insertion in a world where we have to make technology our main ally, both in personal life, as well as in the professional one.

2.2. Digital competences - a conditional factor in the quality of university education

In a digital world, digital competences become the sine qua non condition for participation in education, for extended learning throughout life, for 
continuous personal and professional development, for integration and prompt adaptation to the demands of the socio-professional environment. "Digital competences involve the confident, critical and responsible use of digital technologies, as well as their use for learning, in the workplace, and for participation in society. They include information and data literacy, communication and collaboration, media education, digital content creation (including programming), security (including digital welfare and cybersecurity competences), intellectual property issues, as well as problem solving and critical thinking" (Council Recommendation of 22 May 2018 on key competence for lifelong learning, p. 9).

Being digitally competent requires having a range of knowledge, skills and attitudes, briefly described below, in accordance with the Council of the European Union Recommendation of 22 May 2018 on key competences for lifelong learning. The knowledge subsumed to digital competence integrates aspects such as: the role of digital technologies in communication, in stimulating creativity, the capacity for innovation; opportunities, limits, effects, but also the risks associated with their use; information on their basic function and how to use the various devices, software and networks; criteria on the basis of which content accessed through digital media can be analyzed from the perspective of its validity, reliability and impact; legal and ethical principles.

The action component of digital competence aims at developing the ability to use the digital technologies as a support for active citizenship and social inclusion, collaboration with others and capitalizing on the creativity to achieve various objectives. Digital competences circumscribe their ability to access, select, evaluate, use, but also create, program, and share digital content.

Regarding the attitudinal component, it is important that the interaction with the technologies and the digital content should be "mediated" by a reflective and critical attitude, but doubled by curiosity, openness and future orientation. In addition, the use of digital tools requires reporting on ethical values, responsibility and safety (European Commission, 2019, p. 10). In a report from the European Commission - Digital Economy and Society Index (DESI) 2020. Human capital, it is shown that only 58\% of European Union citizens have at least basic digital competences $(2020$, p. 3). In a digital 
society, these skills allow the consumption of digital goods and services; on the other hand, becoming the creator of such products requires advanced digital competences.

The analysis of the two sub-dimensions circumscribed to human capital from the DESI perspective, namely "internet user skills" and "advanced skills and development", positions Romania, together with Italy and Bulgaria, on the last places in the EU.

Referring to the digital competencies of university professors, in a context in which ensuring the continuity of education in the academic space is conditioned by their presence, a series of studies show that there are not enough basic and intermediate digital competences that make it possible to select and create content for learning, exploring the digital resources needed for the teaching-learning process, so it is very important for professors to develop advanced skills that will allow them to create appropriate digital environments for learning, stimulating and engaging for students, to conceive open educational resources, to integrate ICT constantly in teaching, thus facilitating social innovation (Padilla-Hernández, Gámiz-Sánchez \& RomeroLópez, 2020, p. 122).

In the context of education's digitalization, when access to quality educational resources will be easy, professors are called upon to reflect and promptly identify answers to questions such as: what are the new roles of a professor?; what and how should we evaluate?; how should an effective lesson/lecture/ seminar be? (Frolova, Rogach \& Ryabova, 2020, p. 323).

The organization and development of a quality educational process in the university environment necessarily involves today an attitude of openness to the new, to change, flexibility, creativity, capacity for innovation and, of course, the continuous development of digital competences, and not only, through the efficient integration of modern technologies in the teaching-learningevaluation actions, through the concern to identify and create open educational resources, adapted to the learning needs of students and to their specific particularities. 


\section{Research Questions}

The research questions that guided us in carrying out our investigative approach were the following:

- Are the online educational activities as efficient as the direct ones?

- What is the quality of these activities, in the students' perception?

- What are the main problems that students faced during the online educational activities?

- What are the main ways to optimize online activities?

\section{Purpose of the Study}

The purpose of this research approach is to investigate students' perceptions and attitudes regarding issues relevant to the educational process conducted exclusively online.

The objectives we focused on, derived from the purpose mentioned above, were:

- identifying the perception of students regarding the efficiency and quality of the educational process carried out in the online environment;

- highlighting ways to optimize teaching activities carried out online.

\section{Research Methods}

The main research method used was the questionnaire survey. It was administered online (through Google Forms), integrating a series of items that addressed issues such as: students' participation in educational activities, benefits of online education, problems encountered, solutions for improving the didactic approach carried out in the online environment, the efficiency of the online activities compared to the direct ones, the quality of these activities. The study conducted between June and July 2020 was attended by 256 students from Valahia University of Târgovişte, enrolled in the Psychopedagogical Training Program. In the table below, we present the characteristics of the sample of subjects. 
Table no. 1. Sample characteristics

\begin{tabular}{|c|c|c|c|c|}
\hline $\begin{array}{l}\text { Nr. } \\
\text { crt. }\end{array}$ & \multicolumn{3}{|c|}{ Sample characteristics } & Percentages \\
\hline \multirow[t]{4}{*}{1.} & \multirow[t]{4}{*}{ Age } & \multicolumn{2}{|l|}{$18-20 y$} & $29.7 \%$ \\
\hline & & \multicolumn{2}{|l|}{$21-25 y$} & $32 \%$ \\
\hline & & \multicolumn{2}{|l|}{$26-30 y$} & $7 \%$ \\
\hline & & \multicolumn{2}{|l|}{ over $31 \mathrm{y}$} & $31.3 \%$ \\
\hline \multirow[t]{2}{*}{2.} & \multirow[t]{2}{*}{ Gender } & \multicolumn{2}{|l|}{ female } & $65.6 \%$ \\
\hline & & \multicolumn{2}{|l|}{ male } & $34.4 \%$ \\
\hline \multirow[t]{2}{*}{3.} & \multirow[t]{2}{*}{ The environment of origin } & \multicolumn{2}{|l|}{ urban } & $39.1 \%$ \\
\hline & & \multicolumn{2}{|l|}{ rural } & $60.9 \%$ \\
\hline \multirow[t]{4}{*}{4.} & Program / year of study & \multirow{3}{*}{ Bachelor } & Year I & $53.9 \%$ \\
\hline & & & Year II & $21.9 \%$ \\
\hline & & & Year III & $17.2 \%$ \\
\hline & & \multicolumn{2}{|l|}{ Master } & $7 \%$ \\
\hline
\end{tabular}

The students' answers to a series of items relevant to the investigated problems are analysed (through the Excel statistics package) and interpreted in the next section of our paper.

\section{Findings}

One of the items of the questionnaire asked the students to specify to what extent they used, for the development of educational activities, e-learning platforms/tools/online applications.

Analyzing the distribution of answers (Figure no. 1), we can see that the most used ones were: the Moodle platform of the university (always - 58\%, often $28.1 \%$ ) and the Microsoft Teams application (always $-37.5 \%$, often $26.6 \%$ ). In much smaller proportions, students say they have used other applications/ tools for working online: Zoom, Google Classroom and Cisco WebEx. This distribution of answers demonstrates a unitary vision, in general, of the professors from our university regarding the options for organizing online academic activities, but also the concern to promptly identify, from the first weeks of the pandemic, solutions for continuing the educational process (aspect highlighted by the variety of IT platforms/applications used). Moreover, the use, primarily, of the university's Moodle platform demonstrates its integration, as a support for educational activities, before the crisis had hit. 


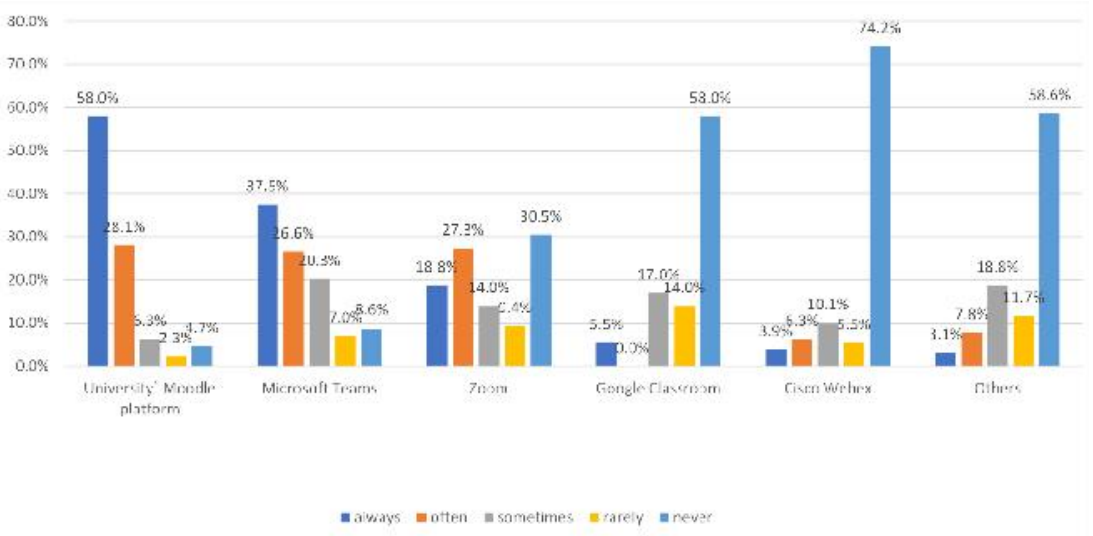

Figure no. 1. Use of e-learning platforms/tools/online applications for carrying out educational activities

The next analyzed item focuses on the efficiency of activities carried out in the online environment, compared to direct activities. Figure no. 2 shows the percentage distribution of answers: $66 \%$ of students consider that online activities do not have the same efficiency as those carried out face to face, $27 \%$ believe that they have the same efficiency, and $7 \%$ of respondents do not offer any appreciation of the efficiency of online activities.

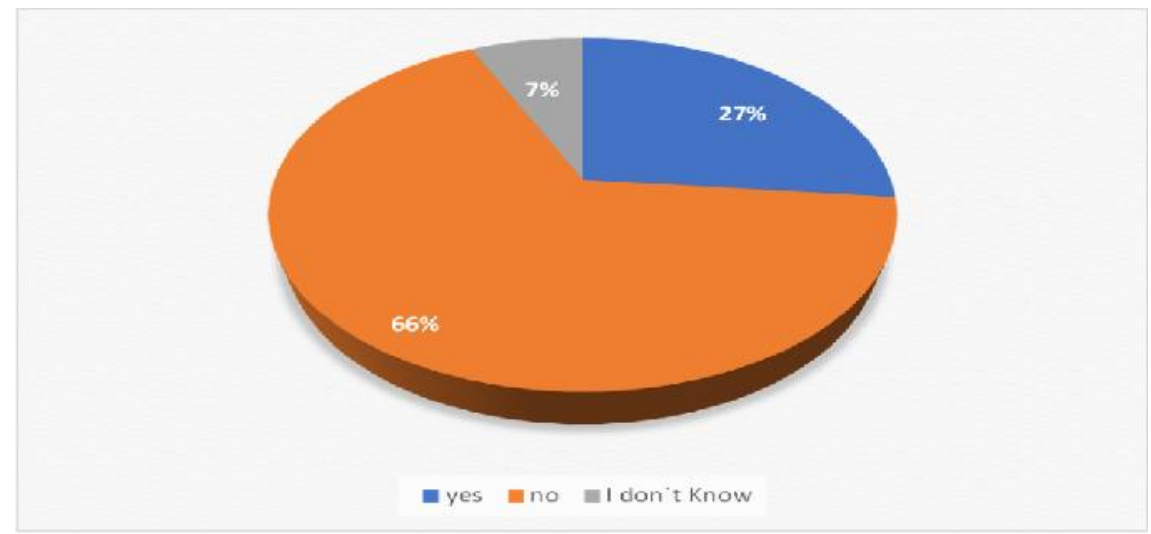

Figure no. 2. The efficiency of the educational activities carried out in the online environment, compared to direct activities (face to face) 
Referring to the answers provided to another item, too, we appreciate that the high percentage of students who highlight the low efficiency of the educational process transferred to the online environment, is explained by a series of technical problems (lack of necessary equipment, poor internet connection), personal problems (stress, fatigue, attention dysfunctions, inadequate physical environment, inconsistent elements of precognition/prerequisites, deficient cultural background, etc.), but also problems generated by an inadequate teaching approach, which does not "adapt itself" on the specificity of the online environment. At the same time, respondents who consider that the two types of activities - online and direct - are generally similar in terms of their efficiency, are generally part of the category of either older or final year students, who have a greater degree of autonomy, can take up the solution of various types of problems, are capable of self-directed learning and have metacognitive competences that make it possible to regulate their own learning process. Distance education requires more discipline and commitment from the student, which may explain why it is associated with success, especially among adults/older people (UNESCO IESALC, 2020).

For the next question, an open-ended one, the students were asked to motivate the answers given to the previous item. In the table below, we present the students' arguments, ordered according to their frequency, from the most frequent to the least present in their answers.

Table no. 2. Arguments regarding the efficiency of the educational activities carried out in the online environment compared to direct activities (face to face)

\begin{tabular}{|c|c|}
\hline \multicolumn{2}{|c|}{ Arguments } \\
\hline Yes & No \\
\hline $\begin{array}{l}\text { - good understanding of courses; } \\
\text { - easy access to course/seminar materials; } \\
\text { - involvement / patience / availability / interest / } \\
\text { professionalism on behalf of the professors; } \\
\text { - time saving; } \\
\text { - very good communication with professors; } \\
\text { - in the conditions of an attitude of the } \\
\text { students characterized by seriousness / } \\
\text { involvement / conscientiousness; } \\
\text { - easy access to activities; } \\
\text { - greater attractiveness; } \\
\text { - advantage for the shy; there are no more emotions } \\
\text { as intense as in face-to-face communication; }\end{array}$ & $\begin{array}{l}\text { - lack of direct interaction / communication } \\
\text { that facilitates both the teaching and the } \\
\text { learning process (understanding); } \\
\text { - lack of understanding / reduced } \\
\text { understanding of the content; } \\
\text { - problems with connection / poor quality of } \\
\text { Internet connection; } \\
\text { - low motivation, in the absence of face-to-face } \\
\text { interaction with professors; } \\
\text { - lack of concentration / diminished attention; } \\
\text { - lack / reduced communication skills specific } \\
\text { to the online environment; } \\
\text { - lack of feedback / poor feedback; }\end{array}$ \\
\hline
\end{tabular}




\begin{tabular}{|c|c|}
\hline \multicolumn{2}{|c|}{ Arguments } \\
\hline Yes & No \\
\hline $\begin{array}{l}\text { - clarity in professors' explanations regarding } \\
\text { certain proposed contents / topics; } \\
\text { - higher presence; } \\
\text { - existence of feedback; } \\
\text { - a better organization of one's own activity by } \\
\text { the student. }\end{array}$ & $\begin{array}{l}\text { - lack of practical activities / difficulties in } \\
\text { carrying out practical activities; } \\
\text { - fatigue; } \\
\text { - impossibility / reduced ability to empathize } \\
\text { with your partner in communication; } \\
\text { - much diminished positive emotional feelings / the } \\
\text { appearance of negative feelings; } \\
\text { - lack of socialization; } \\
\text { - existence of disturbing factors (other family } \\
\text { members, noises in the house, neighbors, etc.); } \\
\text { - lack of student involvement / attitude of } \\
\text { indifference of some students; } \\
\text { - poor digital competences; } \\
\text { - capturing attention difficult to achieve; } \\
\text { - lack of adequate devices; } \\
\text { - evaluation with lower objectivity; } \\
\text { - stress; } \\
\text { - difficulties in achieving the objectives; } \\
\text { - lack of dialogue similar to that of direct } \\
\text { activities; } \\
\text { - lack of clear indications for accomplishing } \\
\text { homework, work tasks; } \\
\text { - increased opportunities for student } \\
\text { involvement in other activities (provided that } \\
\text { video cameras are closed); } \\
\text { - low quality of the educational act made } \\
\text { exclusively online; } \\
\text { - absence of nonverbal communication (given } \\
\text { that the video cameras are closed); } \\
\text { - inability to adequately communicate personal } \\
\text { opinions; } \\
\text { - support materials much too voluminous and } \\
\text { with a high degree of difficulty; } \\
\text { - more sustained pace, the non-existence of } \\
\text { deepening activities; } \\
\text { - short explanations regarding the mistakes of } \\
\text { each student; } \\
\text { - relaxation (of less motivated students). }\end{array}$ \\
\hline
\end{tabular}

Arguments invoked by students who, in a consistent percentage (66\%) consider that the academic activity carried out in the online system is not as efficient as the face-to-face activity, highlights, beyond frequent technical problems, a number of aspects related to the way in which the teaching staff is managing the online education process: from communication, interaction with the students, facilitating and monitoring of the learning process, to the way in which the assessment is performed. All this demonstrates the need for a pedagogical training approach focused on the particularities of 
online education, on didactic principles and strategies that can ensure a more efficient educational activity.

The "appeal" to feedback, both as an argument supporting the efficiency of academic activity carried out in the online environment and as an argument mentioned by respondents who prefer direct activities (those mentioning the lack of feedback or poor feedback), is justified by the fact that the surveyed students are part of different learning communities, respectively different departments and specializations of our university, which means they are reporting to professors with various teaching styles. There are university professors who constantly incorporate feedback into their teaching practices, but there are also professors who do this sporadically or rarely. In addition, as some studies focused on exploring the online learning opportunities offered by Massive Open Online Courses (MOOCs) show, maintaining the quality of interaction and feedback is more difficult in online environment than in the case of face-to-face educational approach (Chircop et al., 2020, p. 11).

Given the negative impact of the problems mentioned by the respondents on the quality of university education, in general, we consider that a pedagogical training approach focused on the particularities of online education, on principles and teaching strategies that can ensure an increased efficiency of the educational activity is needed.

Referring also to those answers of the students that encompass, rather, personal issues and problems, we appreciate that it is necessary to organize groups and individual counseling programs, focused, in particular, on the issue of selfmanagement, management of emotional problems, training/development of metacognitive skills and, of course, digital competences. We can add to these other measures such as: providing guidelines on how to use specific digital tools, software and examination procedures, guides on online learning strategies, extending deadlines for submitting homework, etc. (Gatti et al., 2020).

Another item of the questionnaire focused on the problems that students faced during the online educational activities.

The students appreciated the extent to which they encountered various problems, on a 5-step Likert scale, from a very large extent to a very small extent, referring to a given inventory. 
Table no. 3. Problems identified in the context of online educational activities

\begin{tabular}{|c|c|c|c|c|c|}
\hline \multirow[b]{2}{*}{ Problems } & \multicolumn{5}{|c|}{ Percentages } \\
\hline & $\begin{array}{c}\text { To a } \\
\text { very } \\
\text { small } \\
\text { extent }\end{array}$ & $\begin{array}{c}\text { To a } \\
\text { small } \\
\text { extent }\end{array}$ & $\begin{array}{c}\text { To a } \\
\text { moderate } \\
\text { extent }\end{array}$ & Largely & $\begin{array}{c}\text { To a } \\
\text { very } \\
\text { large } \\
\text { extent }\end{array}$ \\
\hline Lack of adequate devices & $54.8 \%$ & $21.8 \%$ & $13.2 \%$ & $5.5 \%$ & $4.7 \%$ \\
\hline Unable to connect to the Internet & $43 \%$ & $28.9 \%$ & $12.5 \%$ & $10.9 \%$ & $4.7 \%$ \\
\hline Poor internet connection & $28.1 \%$ & $30.5 \%$ & $18.8 \%$ & $11.7 \%$ & $10.9 \%$ \\
\hline $\begin{array}{l}\text { Reduced interaction / communication } \\
\text { with professors }\end{array}$ & $36.7 \%$ & $30.5 \%$ & $18.8 \%$ & $10.1 \%$ & $3.9 \%$ \\
\hline $\begin{array}{l}\text { Reduced interaction / communication } \\
\text { with colleagues }\end{array}$ & $49.2 \%$ & $26.6 \%$ & $13.3 \%$ & $7 \%$ & $3.9 \%$ \\
\hline $\begin{array}{l}\text { Emotional problems (anxiety, } \\
\text { depression, etc.) }\end{array}$ & $48.4 \%$ & $21.1 \%$ & $18 \%$ & $5.5 \%$ & $7 \%$ \\
\hline Overload (high volume of homework) & $24.2 \%$ & $16.5 \%$ & $18 \%$ & $21.8 \%$ & $19.5 \%$ \\
\hline $\begin{array}{l}\text { The absence of the feedback provided } \\
\text { by professors }\end{array}$ & $42.2 \%$ & $24.2 \%$ & $21.8 \%$ & $9.4 \%$ & $2.4 \%$ \\
\hline $\begin{array}{l}\text { Inconsistent feedback provided by } \\
\text { professors }\end{array}$ & $48.4 \%$ & $21.1 \%$ & $20.3 \%$ & $7.8 \%$ & $2.4 \%$ \\
\hline $\begin{array}{l}\text { Reduced skills in autonomous, } \\
\text { independent learning }\end{array}$ & $35.2 \%$ & $29.7 \%$ & $21.8 \%$ & $7 \%$ & $6.3 \%$ \\
\hline $\begin{array}{l}\text { Demotivation (lack of desire to } \\
\text { participate in online educational } \\
\text { activities) }\end{array}$ & $46.9 \%$ & $14.1 \%$ & $15.6 \%$ & $10.2 \%$ & $13.2 \%$ \\
\hline $\begin{array}{l}\text { Fatigue (much too demanding online } \\
\text { educational activities) }\end{array}$ & $28.9 \%$ & $18 \%$ & $26.6 \%$ & $15.6 \%$ & $10.9 \%$ \\
\hline Poor time management skills & $34.3 \%$ & $26.6 \%$ & $18 \%$ & $10.2 \%$ & $10.9 \%$ \\
\hline $\begin{array}{l}\text { Reduced self-management skills } \\
\text { (effective regulation of one's thoughts, } \\
\text { emotions, actions / behaviors) }\end{array}$ & $41.4 \%$ & $26.6 \%$ & $17.2 \%$ & $7.8 \%$ & $7 \%$ \\
\hline $\begin{array}{l}\text { Difficulties in learning, understanding } \\
\text { and operating with certain contents }\end{array}$ & $31.3 \%$ & $31.3 \%$ & $21.8 \%$ & $5.5 \%$ & $10.1 \%$ \\
\hline $\begin{array}{l}\text { Lack of guidance needed to facilitate } \\
\text { learning }\end{array}$ & $36.7 \%$ & $27.4 \%$ & $19.5 \%$ & $8.6 \%$ & $7.8 \%$ \\
\hline $\begin{array}{l}\text { Reduced guidance provided by } \\
\text { professors to facilitate the learning }\end{array}$ & $43 \%$ & $25 \%$ & $18.7 \%$ & $6.3 \%$ & $7 \%$ \\
\hline Poor digital competences & $49.2 \%$ & $25.8 \%$ & $18 \%$ & $7 \%$ & $0 \%$ \\
\hline $\begin{array}{l}\text { Difficulties in creating practical } \\
\text { applications / themes }\end{array}$ & $37.5 \%$ & $30.5 \%$ & $16.5 \%$ & $10 \%$ & $5.5 \%$ \\
\hline $\begin{array}{l}\text { Absence of RED (open educational } \\
\text { resources) }\end{array}$ & $48.4 \%$ & $28.1 \%$ & $16.5 \%$ & $5.5 \%$ & $1.5 \%$ \\
\hline $\begin{array}{l}\text { Reduced access to RED (open } \\
\text { educational resources) }\end{array}$ & $46.9 \%$ & $27.4 \%$ & $14.8 \%$ & $8.6 \%$ & $2.3 \%$ \\
\hline $\begin{array}{l}\text { Absence of counseling (performed by } \\
\text { professors / tutors) }\end{array}$ & $45.3 \%$ & $24.2 \%$ & $16.5 \%$ & $8.6 \%$ & $5.4 \%$ \\
\hline $\begin{array}{l}\text { Inconsistent counseling approaches } \\
\text { (performed by professors / tutors) }\end{array}$ & $52.3 \%$ & $20.3 \%$ & $14.1 \%$ & $7 \%$ & $6.3 \%$ \\
\hline $\begin{array}{l}\text { Absence of professors' concerns to } \\
\text { differentiate / individualize the training }\end{array}$ & $46.8 \%$ & $21.1 \%$ & $16.4 \%$ & $9.4 \%$ & $6.3 \%$ \\
\hline Difficulties in doing group work & $50 \%$ & $19.5 \%$ & $14.8 \%$ & $13.3 \%$ & $2.4 \%$ \\
\hline $\begin{array}{l}\text { Difficulties in expressing my opinion / } \\
\text { making myself heard in the online } \\
\text { environment }\end{array}$ & $46.9 \%$ & $21.1 \%$ & $21.8 \%$ & $6.3 \%$ & $3.9 \%$ \\
\hline $\begin{array}{l}\text { Emphasizing forms of the } \\
\text { cyberbullying }\end{array}$ & $63.3 \%$ & $21.8 \%$ & $8.6 \%$ & $3.9 \%$ & $2.4 \%$ \\
\hline
\end{tabular}


Analyzing the distribution of students' responses regarding the appreciation of problems in online activities (Table no. 3), we can note that most of the answers located at the top of the scale (which means that those obstacles manifested to a large extent and to a very large extent) are associated with the following aspects: overload (high volume of homework), fatigue (much too demanding online educational activities), poor Internet connection, demotivation (lack of desire to participate in online educational activities) and poor time management competences.

Moreover, the results of our investigation are reinforced by data provided by other studies and reports, which show that most of the students surveyed reported a higher workload, problematic access to online and internet communication tools, poor level of digital competences, as well as the prevalence of negative emotions such as: boredom, anxiety, frustration, anger, etc. (Aristovnik et al., 2020; Farnell et al., 2021; World Bank, 2020).

The quality of the educational activities carried out in the online environment was another issue on which we asked the students to make assessments. The scale used for this item was one with 5 steps, from very good to very bad.

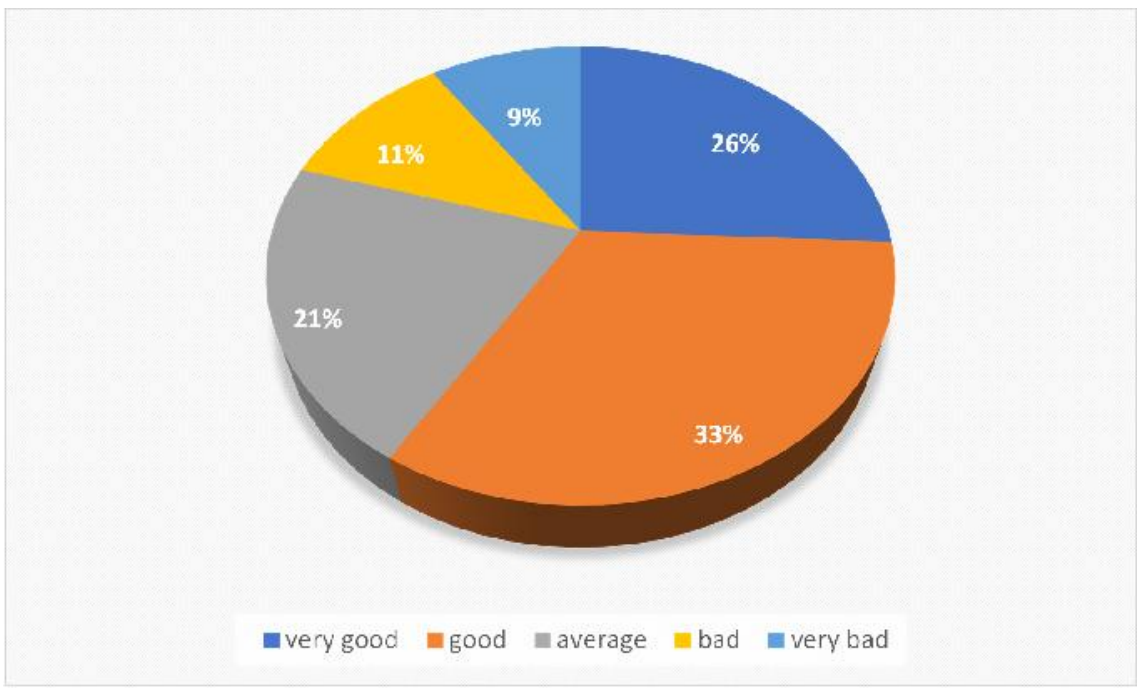

Figure no. 3. Appreciating the quality of educational activities carried out in the online environment 
In the figure no. 3 we can see the students' options for each of the five steps of the scale. So, $26 \%$ of the respondents appreciate that the online educational activity had a very good quality, $33 \%$ - good, $21 \%$ - average, $11 \%$ - bad and $9 \%$ - very bad.

The percentage of $59 \%$ of the respondents who satisfied with the quality of online education demonstrate, as mentioned above, a concern of most university professors to continue to ensure a student-centered education, making the most of their own teaching expertise and articulating solutions to problems, difficulties specific to educational contexts that they had not faced until then.

A topic for reflection for each of the professors, remains the following: how they can optimize the academic activity in the conditions in which it is possible that, in the future, its online component will have an important part.

At the end of the questionnaire, was included an item that asked the subjects for suggestions, recommendations for optimizing the educational approaches conducted in the online environment. A percentage of $31.2 \%$ of the surveyed students consider that there is no need to change, improve any aspect and do not present recommendations/suggestions for improving online activities. The others make a series of suggestions, recommendations, which we will present briefly in the table below, in the order of frequency.

Table no. 4. Students' suggestions/recommendations of students to improve educational activities carried out online

\begin{tabular}{l} 
Suggestions/recommendations of the students \\
\hline - \\
- \\
- \\
adequate of the same platform/application for all the teaching activities; \\
- providing more explanations/more consistent guidance from professors; \\
ensuring more interactivity in teaching activities, using interactive sites/applications \\
(where possible) to make the online educational experience more interesting and to \\
facilitate the understanding of the contents; \\
- purchasing services that provide a better internet connection; \\
manifesting an extra empathy and understanding on behalf of professors in relation to \\
- students' personal, emotional problems; \\
organizing courses for the development of digital competences of students/professors; \\
better exploitation of the learning resources offered by the online environment/online \\
bibliography;
\end{tabular}




\begin{tabular}{|c|}
\hline Suggestions/recommendations of the students \\
\hline 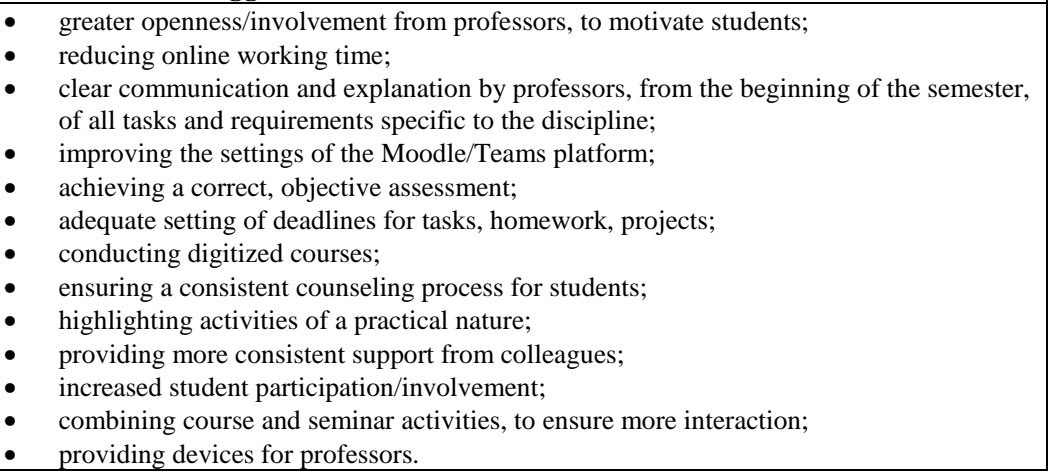 \\
\hline
\end{tabular}

\section{Conclusions}

Following the investigative approach, we mention as main conclusions, the following:

- the majority of students surveyed (66\%) consider that educational activities conducted in the online environment are not as efficient as direct (faceto-face) activities;

- the main arguments that students bring in support of this position regarding the reduced efficiency of online activities are: the lack of direct interaction/ communication, the lack of understanding or poor understanding of content, connection problems/poor quality of Internet connection, low motivation, the lack of face-to-face interaction with professors, the lack of concentration/diminished attention, the lack/reduced communication skills specific to the online environment and the lack of feedback/poor feedback;

- regarding the respondents' perception of the quality of online educational activity (without comparing it with direct activity, but analyzing only the resources available in the online environment, the efforts made by professors to design and carry out this activity), most appreciate that it was very good and good (cumulative percentages of 59\%), as a result of the joint efforts of the professors and the students alike;

- the most important problems generated by the transfer of academic activities in the online environment were the following: overload (high volume of homework), fatigue (too demanding educational activities), poor Internet connection, demotivation and poor time management skills; 
- as suggestions/recommendations for improving online educational activities, students frequently mentioned the following aspects: the proper amount of homework/tasks that involve independent work, the use of the same platform/application for all teaching activities, the better interaction with professors, providing more explanations/more consistent guidance from professors, ensuring more interactivity in teaching activities, the use of interactive sites/applications (where possible) to make the online educational experience more interesting and to facilitate the understanding of the contents.

In conclusion, it is important that the lessons we have all learned during this period are a starting point for what must be the "makeover" of university education, through digitization, by promoting an innovative teaching approach, based on a mixed format, in which direct activities, of rigorous guidance and directing of learning, to alternate with those that offer a high degree of independence and autonomy to students, being mediated by ICT.

However, there is a need for a new pedagogical vision, a willingness to change, an attitude of trust, first of all, in the transformative virtues of technology and in its facilitating role for the teaching-learning-assessment process (in the conditions of integration and effective use, of course), advanced digital competences and institutional support and adequate support for professors and students on a path of no return and the right to choose: that of digitization.

Beyond the challenges, advantages and limitations, we must not forget that, in the context of the Covid 19 pandemic, the migration of education in the online environment was the saving solution to ensure the continuity of the learning process, but it was also the way to protect the health and life of all participants in the educational process (Almazova et al., 2020).

\section{NOTES}

1. The contribution of the authors to this paper is equal.

2. The whole research respected the actual ethical standards and the participants expressed their consent to take part in this research. The authors thank to the participants in this research. 


\section{References}

- Almazova, N., Krylova, E., Rubtsova, A., \& Odinokaya, M. (2020). Challenges and Opportunities for Russian Higher Education amid COVID-19: Professors' Perspective. Education Sciences, 10(12), 1-11.

https://doi.org/10.3390/educsci10120368

- Area-Moreira, M., Bethencourt-Aguilar, A., \& Martín-Gómez, S. (2020). De la enseñanza semipresencial a la enseñanza online en tiempos de Covid 19. Visiones del alumnado [From blended teaching to online teaching in the days of Covid 19. Student visions]. Campus Virtuales, 9(2), 35-50.

- Aristovnik, A., Keržič, D., Ravšelj, D., Tomaževič, N., \& Umek, L. (2020). Impacts of the COVID-19 Pandemic on Life of Higher Education Students: A Global Perspective. MDPI.

- Chircop, D., Schomaker, L., Karakas, C., Kiss, M., \& Szczepanski, M. (2020). The future of tertiary education in Europe. European Union.

- European Commission. (2019). Key Competences for Lifelong Learning. Publications Office of the European Union.

- European Commission. (2019). The 2018 International Computer and Information Literacy Study (ICILS). Main findings and implications for education policies in Europe. Publications Office of the European Union.

- European Commission. (2020). Education and Training Monitor 2020. Teaching and learning in a digital age. Publications Office of the European Union.

- European Commission. (2020). Digital Economy and Society Index (DESI) 2020. Human capital. Publications Office of the European Union.

- European Commission/EACEA/Eurydice. (2020). The European Higher Education Area in 2020: Bologna Process Implementation Report. Publications Office of the European Union.

- Farnell, T., Skledar Matijević, A., \& Šćukanec Schmidt, N. (2021). The impact of COVID-19 on higher education: a review of emerging evidence, NESET report. Publications Office of the European Union. https://doi.org/10.2766/069216

- Frolova, E., Rogach, O., \& Ryabova, T. (2020). Digitalization of Education in Modern Scientific Discourse: New Trends and Risks Analysis. European Journal of Contemporary Education, 9(2), 313-336.

- Gatti, T., Helm, F., Huskobla, G., Maciejowska, D., McGeever, B., \& Pincemin, J.-M. (2020). Practices at Coimbra Group universities in response to the COVID-19: A collective reflection on the present and future of higher education in Europe. The Coimbra Group. https://www.coimbra-group.eu/wp-content/uploads/FinalReport-Practices-at-CG-Universities-in-response-to-the-COVID- 19.pdf

- Hodges, C., Moore, S., Lockee, B., Trust, T., \& Bond, A. (2020, March 27). The difference between emergency remote teaching and online learning. Educause review. 
- Kalantzis, M., \& Cope, B. (2020). After the COVID-19 crisis: Why higher education may (and perhaps should) never be the same. Educational Philosophy and Theory, 40(1), 51-55. https://doi.org/10.46786/ac20.9496

- Klemenčič, M., Pupinis, M., \& Kirdulytë, G. (2020). Mapping and analysis of student-centred learning and teaching practices: usable knowledge to support more inclusive, high-quality higher education, NESET Report. Publications Office of the European Union. https://doi.org/10.2766/67668

- OECD. (2020). Resourcing Higher Education: Challenges, Choices and Consequences. OECD Publishing. https://doi.org/10.1787/735e1f44-en

- O'Keefe, L., Rafferty, J., Gunder, A., \& Vignare, K. (2020). Delivering highquality instruction online in response to COVID-19: Faculty playbook. Every Learner Everywhere. http://www.everylearnereverywhere.org/resources

- Padilla-Hernández,A. L., Gámiz-Sánchez, V., \& Romero-López,A. (2020). Evolución de la competencia digital docente del profesorado universitario: incidentes críticos a partir de relatos de vida. Educar, 56(1), 109-127.

https://doi.org/10.5565/rev/educar.1088

- UNESCO IESALC. (2020). COVID-19 and higher education: Today and tomorrow. Impact, analysis, policy responses and recommendations. UNESCO IESALC. http://www.iesalc.unesco.org/en/wp-content/uploads/2020/04/COVID19-EN-090420-2.pdf

- World Bank. (2020). Tertiary education and COVID-19: Impact and mitigation strategies in Europe and Central Asia. World Bank.

http://documents1.worldbank.org/curated/en/783451590702592897/COVID-19Impact-on-Tertiary-Education-in-Europe-and-Central-Asia.pdf

- ***. (2018). Council Recommendation of 22 May 2018 on key competence for lifelong learning. Oficial Journal C 189, 4.6.2018, pp. 1-13.

The online version of this article can be found at: http://revped.ise.ro/category/2021-en/

\section{(oc) EY-NC-BA}

This work is licensed under the Creative Commons Attribution-NonCommercial-ShareAlike 4.0 International License.

To view a copy of this license, visit http://creativecommons.org/licenses/by-nc-sa/4.0/ or send a letter to Creative Commons, PO Box 1866, Mountain View, CA 94042, USA.
Versiunea online a acestui articol poate fi găsită la: http://revped.ise.ro/category/2021-ro/

\section{(c) D DY-NC- $B A$}

Această lucrare este licen iată sub Creative Commons Attribution-NonCommercial-ShareAlike 4.0 International License.

Pentru a vedea o copie a acestei licen e, vizita $i$ http://creativecommons.org/licenses/by-nc-sa/4.0/ sau trimite i o scrisoare către Creative Commons, PO Box 1866, Mountain View, CA 94042, SUA. 